Datokarama English Education Journal Vol. 2 No. 1,2021

\title{
IMPROVING STUDENTS' PRONUNCIATION \\ OF MONOPHTHONG SOUND IN READING \\ NARRATIVE TEXT BY USING CHORAL \\ READING TECHNIQUE AT THE EIGHTH \\ GRADE STUDENTS OF MTS ALKHAIRAT \\ ALINDAU
}

\author{
Yuli Nursyam \\ Rusli \\ Zuhra \\ Rasmi
}

\begin{abstract}
Study Program of English, Tadris Faculty of Tarbiyah and Teacher Training
State Institute for Islamic Studies (IAIN) Palu

E-mail:Yulinursyam99@gmail.com
\end{abstract}

\begin{abstract}
This research discusses about the use of Choral Reading in reading narrative text. The purpose of this research was to determine whether the choral reading technique affects students' pronunciation. The researcher used a quasi-experimental research design, the population in this research is class VIII Mts Alkahirat Alindau which consists of two classes, they are class $8 \mathrm{~A}$ and $8 \mathrm{~B}$. In this research, class $8 \mathrm{~B}$ as the Experimental Group by usinga purposive sampling technique. In the experimental class, the researcher gave a pre-test, treatment (choral reading), and post-test, while for the control class, only pretest and post-test without treatment. The researcher collected data through a reading test. From the calculation of the data it showed that the difference in students' scores on the pre-test and posttest with an average post-test score was higher than the average of pre-test score $(67.06>30.26)$. This can be seen from the results obtained before and after the treatment, the score on post-test of experimental class was higher than the score on the pos-test of control group (67.0>51.2). In addition, the result showed that the t-counted was higher than the t-table (52.94>2084. Based on the data analysis, the researcher concluded that the used of Choral Reading technique was affects the pronunciation of the 8th grade students of MTs Alkharat Alinda.
\end{abstract}

Keyword : Improving, Pronunciation, Choral Reading, Narrative text. 
Datokarama English Education Journal Vol. 2 No. 1,2021

\section{Background}

English is an international language used by people all over the world even in the world of technology and in the world of work. English can be applied in many aspects, such as: education, society, politics, economy, and culture.

As the key of communication, language has an important role to reveal an intention or convey something to someone else. Many people learn English because they think that it will be useful in a variety of ways for international communication.

In Indonesia, English has been taught as a foreign language. Therefore, our government makes policies regarding the usage of English, especially in the field of education. Standards competence of Junior High School states that the goal of teaching English at Junior High Schools is possible for students to get a level of functional literacy. It means that, teaching English as a foreign language involves the students have to be able to convey English in an articulate and engaging way. The teachers have to encourage the students to improve their English skills through listening, speaking, reading and writing.

However, some English teachers do not integrate their teaching and learning process in the classroom. For example; when they teach structure, they just focus on it and do not pay attention to the other skills. So, there are many students difficult in improve their English skill.

Based on the pre-observation that had been done by the researcher at the MTs Alkhairat Alindau, the students had difficulties in pronouncing the words and lacks of confidence in reading loudly. So the researcher decided to conduct the research entitled, Improving Students' Pronunciation by Using Choral Reading Technique at this school.
Choral reading technique is a literacy technique that helps students build the students' fluency, self-confidence, and motivation in reading. During the teaching and learning process by using choral reading, a student, or a group of students reads a passage together, with or without a teacher. So the researcher thinks that this technique can be enjoyable for student and the integrated of the teaching learning process can be achieved.

\section{Literature Review}

\subsection{Pronunciation}

1. Definition of Pronunciation.

Pronunciation is the language feature that most readily identifies speakers as nonnative. ${ }^{1}$ Since it can be identified as non-native, we do not need to pronounce as the way native speakers do. However, we need to be minimally intelligible while speaking. She added that when we find students that find difficulty in speaking, we as teachers need to assist them through improving their pronunciation. Pronunciation is never end in itself but a means of negotiating meaning in the discourse, embedded in specific socio-cultural and interpersonal contexts." Producing sentences can have a different meaning related to the way people pronounce sentences. Indeed, pronunciation needs to be taught to students. $^{2}$

\footnotetext{
${ }^{1}$ Yanuarria Kukuh Perwira, "(a case of the
} fifth semester students of the english department of english department faculty of languages and arts" (2011).

${ }^{2}$ Dwi Riyanti Dyna Ariyani, Rismaya Marbun, 'Improving Students' Pronunciation By Using Reading Aloud In Junior High School," Jurnal Pendidikan dan Pembelajaran Khatulistiwa (2013): 1-9, 


\section{Datokarama English Education Journal Vol. 2 No. 1,2021}

Pronunciation is one of the essential nouns based in an oral form and the basic ability to speak English as well as other languages. The correct pronunciation of English is to help the students to pronounce correctly. Clear pronunciation makes the students easy to understand and produce intelligible sounds. The study of pronunciation has become an important aspect in teaching English as a Foreign Language. In the learning process, the students may faced difficulty in pronouncing the English words and pronunciation had become a dilemma for students.

So pronunciation is one of the most important components in English that we need to know as foreign language learners. because with good pronunciation, we can get clear information and make it easier for us to communicate with foreign speakers especially in English. in pronunciation, there are also several parts, among others: consonants, vowels, and so on. in consonants there are 2 sounds are voice and voiceless, while in the vowel, there are two sounds are diphthong and monophthong. Diphthong produces two sounds in one word while monophthong produces one sound in one word. By learning pronunciation, we understand about everything that the interlocutor or native speaker is talking about, besides that pronunciation makes us easier to give or receive information from others.

2. The Main Features of Pronunciation

In order to study how something works it is often useful to break it down into its constituent parts. The following diagram shows a breakdown of the main features of pronunciation.

https://jurnal.untan.ac.id/index.php/jpdpb/article/vi ew/3413.

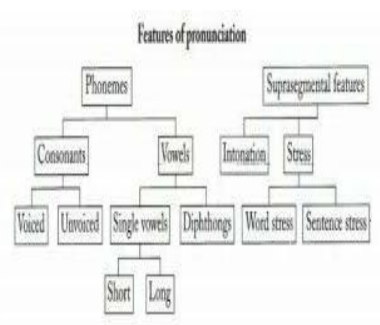

Based on the diagram above, the main features of pronunciation into two categories. The first is phonemes, there are two branches of phonemes, they are consonants and vowels. ${ }^{3}$ The consonant consist of voiced and voiceless, while vowel consist of monophtong and diphthong and the second is suprasegmental features. There are two kinds of suprasegmental features. They are intonation and stress. For the detail explanation of the phonemes and suprasegmental feature stated as follows:

\section{a. Phonemes}

In describing the sound-system of any language, it is necessary to understand what the phoneme is. Phoneme is a class of sounds. A phoneme is one of set of abstracts unit that can be used for writing language down in systematic and unambiguous way. E.g. town down /taun//daun/. Phoneme is each one of these meaning-distinguishing sounds in language. The basic phonemes of English are listed in the consonant and vowel.

\section{Consonant}

In teaching pronunciation, English consonants can be grouped according to the sounds produced.Consonants are kinds of sounds that are produced by interrupting, restricting, or diverting the airflow in some ways.In English the

\footnotetext{
${ }^{3}$ Nona Awalul Laily, "Improving Student' Pronunciation by Using Reading Aloud Technique at the Sevent Grde of SMPN 3 Kedungwaru Tulungagung."
} 
Datokarama English Education Journal Vol. 2 No. 1,2021

following consonants are voiced: [b], [d], $[\mathrm{g}],[\mathrm{v}],[\mathrm{z}],[3],[\mathrm{d}],[\mathrm{y}],[\mathrm{l}],[\mathrm{r}],[\mathrm{j}],[\mathrm{w}]$, $[\mathrm{m}],[\mathrm{n}]$, and [ð].

\section{Vowel}

Having described consonants above, it is also important in teaching pronunciation to know about vowels. Describes that vowels are articulated when a voiced airstream is shaped using the tongue and the lips to modify the overall shape of the mouth. Meanwhile, vowel sounds are produced with a relatively free flow of air. ${ }^{4}$ Vowels are speech-sounds in which the air stream can pass freely through and out of the mouth. (e.g. [a:], [i:], [u:], [o:], etc.). ${ }^{5}$ Vowel sounds are all voiced, and maybe single (like /e/, as inlet), or a combination, involving a movement from one vowel sound to another (like /eI/, as in late); such combinations are known as diphthongs. ${ }^{6}$ In articulating vowel sounds, vowels are articulated when a voiced airstream is shaped using the tongue and the lips to modify the overall shape of the mouth. The characteristics of vowel include the following: ${ }^{7}$

\footnotetext{
${ }^{4}$ Wildan Habibi, "English Pronunciation Problems Encountered By Indonesian Advanced Students," Faculty Of Humanities Maulana Malik Ibrahim State Islamic University Of Malang (2016).

${ }^{5}$ Aniq Mukhoyyar, “An Error Analysis Of The English Vowels Pronunciation In Speaking For Instructional Purposes Of The Fifth Semester Students Of English Education Department Of Teacher Training And Education Faculty Of Muria Kudus University In The Academic Year 2013/2014" (2015).

${ }^{6}$ Risya Putri Dia Ocvika, "TeachingLearning Pronunciation Through Reading Aloud Technique At The Second Semester Of The Eighth Grade Of SMP Negeri 2 Gading Rejo 2016/ 2017 Academic Year," Tarbiyah And Teacher Training Faculty Raden Intan State Islamic University of Lampung 4 (2017): 9-15.

${ }^{7}$ Ibid, 78
}

\section{Pure Vowel}

The word pure here is used to differentiate single vowel sounds from diphthong, which we will consider later.

\section{Close Vowel}

For close vowels, the tongue is quite high in the mouth. Moving from /i:/ through to $/ \mathrm{u}: /$, we also notice the different positions of the tongue; /i:/ is a front vowel, and /u:/ is a back vowel.

\section{Mid Vowel}

For mid vowels, the tongue is neither high nor low in the mouth. Moving from /e/ through to / $\mathrm{s} / /$, we also notice the different positions of the tongue; /e/ is a front vowel, and / $/$ :/ is a back vowel.

\section{Open Vowels}

For open vowels, the tongue is low in the mouth. Moving from /æ/through to $/ \mathrm{p} /$, we also notice the different positions of the tongue; $/ \Re /$ is a front vowel, and $/ \mathrm{p} /$ is a black vowel.

\section{Monophthongs}

Monophthongs are a single sound, with the articulators in one position throughout and therefore no change in the sound quality. ${ }^{8}$ The term monophthongs is as single vowels. ${ }^{9}$ Single vowels can be described in terms of how long they are, as well as the position of our tongue and the shape of our lips when we say them. There two kinds of monophthongs or single vowels, they are short and long vowels. A short vowel is a simple (non-complex) vocalic segment occurring within the nucleus of a syllable, and long vowels are

\footnotetext{
${ }^{8}$ Amiyatul Fikriyah, “An Analysis Of The Students ' Ability In By : Amaliyatul Fikriyah Of Teacher Training And Education Faculty State Institute For Islamic Studies ( Iain ) Salatiga" (2019).
} 


\section{Datokarama English Education Journal Vol. 2 No. 1,2021}

vowels associated with two X-slots within the syllabic nucleus. ${ }^{10}$

Table 2.5 List of Short and Long Vowels Single Vowels

\begin{tabular}{|c|c|}
\multicolumn{1}{l}{ Short } & Long \\
\hline I - bin & a: - hee \\
\hline e - pen & o: - four \\
\hline o- boat & a: - far \\
\hline$\Lambda$ - fun & $3:-$ bird \\
\hline o- about & u: - blue \\
\hline$\mho-$ look & \\
\hline$x$ - man & \\
\hline
\end{tabular}

(Source: Yates and Zielinski, 2019: 54)

\section{Diphthong}

In teaching pronunciation, besides consonants and vowels, we must also recognize diphthong. A diphthong might be a combination of vowel sounds that there is a glide (or movement of the tongue, lips, and jaw) from one pure vowel sound to another. In diphthong, the first sound of each phoneme is longer and louder than the second sound inEnglish, not in other languages.

b. Suprasegmental Features

Suprasegmental features are features of speech which generally apply

\footnotetext{
${ }^{10}$ Yolla Kharisma Desrizon and Don Narius, "Journal of English Language Teaching Improving Pronunciation In Teaching Speaking Of Senior High School Students Through English Films," Journal of English Language Teaching 6, no. 1 (2017): 117-123.
}

to groups of segments, or phonemes. The features that are important in English are intonation and stress.

\section{1) Intonation}

The term intonation refers to the way the voice goes up and down in pitch when we are speaking. It is a fundamental part of the way we express our own thoughts and it enables us to understand those of other.

\section{2) Stress}

The second features of suprasegmental feature of pronunciation is stress. The degree of force with which a sound or syllable is uttered. One of the syllables in each word will sound louder than others. The syllables indicated in capitals are the stressed syllables.

\subsection{Choral Reading}

Choral reading is one of the reading strategies can be used to build students' reading fluency. It helps students to build their self-confidence and motivation in reading. ${ }^{11}$

Student, or a group of students reads a passage together, with or without a teacher. Choral reading can be done individually, in small groups, or as a whole class. The students are reading aloud together, those who may ordinarily feel nervous about reading aloud may have built-in support with their group.

Choral reading is well suited for the short story, poetry, rhymes, and dialogues. Choral reading allows students to try out language. It also helps students improve their sight vocabulary and develop oral language skills.

Beside that, choral reading is also an enjoyable and an engaging method to employ. Having students read at a

\footnotetext{
${ }^{11}$ Stange, Kimberly. 2007. Using Reader's Theater and Choral Reading to Improve First Grade Regular Education Students' Fluency. Florida: University of Florida
} 


\section{Datokarama English Education Journal Vol. 2 No. 1,2021}

significant point in a selection can increase suspense or express an emotional reaction intended by the author.

In this technique, there is a leader as a guide to read the text. The leader reads loudly and the other students will follow the leader. Choral reading is an interpretive reading of the text by a group of voices. Students may read individual lines or stanzas alone, in pairs, or unison. The teacher also reads to help set the pace, as well as model proper pronunciation. So, in choral reading, the teacher leads the entire group reading aloud in unison. The students are given a reading passage and a model of fluent reading, students will read the text fluently and with expression.

1. Steps of Choral Reading Technique.

There are sixsteps of choral reading technique. $^{12}$

1) The teacher distributes the reading material and reviews words anticipated to be difficult.

2) The teacher asks the students to discuss the passage to activate their background knowledge as an aid to comprehension.

3) Then, the teacher reads the passage loudly with appropriate pronunciation and expression while students read along silently.

4) Then the teacher asks students to read the passage together after the teacher gives a clue by counting down aloud "three-two-one".

${ }^{12}$ supiningsih, "Upaya Meningkatkan Kemampuan Membaca Dalam Pelajaran Bahasa Inggris Dengan Strategi Choral Reading Melalui Powerpoint," Wacana Akademika: Majalah Ilmiah Kependidikan 1, no. 2 (2017): 165-174.
5) While students reading the passage together, the teacher simultaneously listens for words and phrases that students get difficulty pronouncing.

6) After reading together finish, the teacher reviews again the difficult words and phrases to reinforce appropriate pronunciation.

\subsection{Definition of Narrative Text}

Narrative text is one of the English text types, the purpose of the narrative text is to entertain the reader or listener. ${ }^{13}$ However, narrative can also be written to teach or inform, to change attitudes or social opinions, and to show the moral of a story. The generic structures of narrative texts are : (a) Orientation which introduces the main characters and possibly some minor characters. Some indication is generally given of where the action and when an action happened. Complication where the writer tells how the problem arises, sometimes something unexpected events will happen. (c)The resolution is an optional closure of the event. The complication may be resolved for better or for worse, but it is rarely left completely unresolved. The narrativetext are divided into two kinds, they are .Nonfiction is a kind of narrative writing that tells the true story and fiction is a kind of narrative that tells an untrue story.

\footnotetext{
${ }^{13}$ Dhea Fernanda, "The Use Of Animation Video To Improve Students' Reading Comprehension In Narrative Text To The Second Grade Students Of Smpn 1 Lahat, South Sumatera," English Education Study Program Department Of Language And Art Education Faculty Of Teacher Training And Education University Of Lampung 2, no. 2 (2019): 36-44.
} 


\section{Datokarama English Education Journal Vol. 2 No. 1,2021}

\section{Methodology}

In this research, the researcher used quasi experimental research design in order to find out the data and results of tests. Therefore, there two groups as the subject of this research. Those are class VIII B as the experimental group and VIII $A$ as the control group. These two groups took from population of class VIII students of MTs AlkhairatAlindau. The researcher conducted two kinds of tests, they are pretest and post-test. Both experimental and control group gave a pre-test. The researcher did a pre-test in order to measure the reading ability of the students in pronouncing the monophtong sounds. The post test also gave for both of the groups, but the treatment only gave for the experimental group.

The quasi-experimental design is described in the table is following: ${ }^{14}$

\begin{tabular}{|l|l|l|l|}
\hline Select & Pre & Control & Po \\
Control Group & - & No & st- \\
& test & Treatment & test \\
\hline Select & Pre & Experimen & Po \\
Experimental & - & t & st- \\
Group & test & Treatment & test \\
\hline
\end{tabular}

\section{Result and Discussion}

After knowing the results of the calculations above, the researchers concluded that there is difference between experimental post test mean group and post test control group. the average value in the post-test experiment group (67.06) was higher than the average post test of the control group (51.2), where $\mathrm{Mx}>\mathrm{My}$. The calculation result of $\mathrm{t}$-counted $=52.94$ while the calculation result of t-table $=$

\footnotetext{
${ }^{14}$ John W. Creswell, Educational

Research: Planing, Conducting, and Evaluating Quantitative and Qualitative Research, Third Edition, (New Jersey: Person Education. 2008)
}

2.084. So, t-count is greater than t-table. Based on these results, it means that there is a significant difference the score between the post-test of the experimental group and the post-test of the control group.

The researcher started the experiment by giving a pre-test to find out students before receiving treatment. Pretest results between the experimental group and the control group were not much different, because the average pretest of the experimental group (36.8) is slightly lower than or similar with the mean of the pre-test control group (40) where Mx My; second groups have almost the same ability. The results of this study are the post-test scores of the experimental group was higher (67.06) than the post-test score of control group (51.2). So, based on the explanation above, the researcher concluded that using the choral reading technique proved to be better in students' pronunciation skills in reading texts compared to students who are taught without using choral reading techniques because as we know that pronunciation is one of the important components in English that must be practiced continuously, with clear and correct pronunciation it will be easier to get good information. It means that there is a significant difference in students' pronunciation ability between those who used the choral reading technique and those who did not use the choral reading technique.

\section{Conclusion and Suggestion}

\subsection{Conclusion}

There is a difference in students' reading ability between the experimental group (treated with the choral reading technique) and the control group (without treatment). before each reading without treatment in the pre-test for the experimental 
Datokarama English Education Journal Vol. 2 No. 1,2021

class (30.8), the average value was slightly lower than the pre-test for the control class (40). after the researcher gave treatment to the experimental class posttest, then the average post-test score of the experimental group $(\mathrm{Mx}=67.06)$ was higher compared to the mean score of the control group post-test $(\mathrm{My}=51.2)$. so $(\mathrm{Mx}>\mathrm{My} / 67.06>51.2)$. The data from the calculation shows the experimental group was better than the control group. So, the coral reading technique has a positive effect on students' pronunciation skills in reading narrative texts in class VIII MTs Alkhairat Alindau.

\subsection{Suggestion}

Based on the conclusions above, the researcher would like to suggest the following:

1. To the Teacher

The teacher has an important role and a great influence in the success of student learning. Teachers must be more creative in choosing learning techniques in the classroom so that students do not feel bored and can easily understand the material being taught.

2. To the Student

It is expected that students should be more active during the teaching and learning process of English in the classroom. The students must repeat at home the material that has been given by the teacher.

3. To the Researcher

From the results of the study, it is known that using choral reading techniques can improve students' pronunciation. With this expected learning outcomes make English teachers use appropriate techniques to improve students' pronunciation. In addition, the research results can be used as a reference for further research with different samples. 
Datokarama English Education Journal Vol. 2 No. 1,2021

\section{References}

Yanuarria Kukuh Perwira. A case of the fifth semester students of the english department of english department faculty of languages and arts. 2011.

Dwi Riyanti Dyna Ariyani, Rismaya

Marbun. Improving Students'

Pronunciation By Using Reading

Aloud In Junior High School, Jurnal

Pendidikan dan Pembelajaran

Khatulistiwa; p.1-9,

https://jurnal.untan.ac.id/index.php/j

pdpb/article/view/3413. 2013.

Nicky Dwiningrum. The Teaching Of English Pronunciation To Young Learners. 2016.

Nona Awalul Laily. Improving Student' Pronunciation by Using Reading Aloud Technique at the Sevent Grde of SMPN 3 Kedungwaru Tulungagung.

Wildan Habibi. English Pronunciation Problems Encountered By Indonesian Advanced Students, Faculty Of Humanities Maulana Malik Ibrahim State Islamic University Of Malang. 2016.

Aniq Mukhoyyar. An Error Analysis Of The English Vowels Pronunciation In Speaking For Instructional Purposes Of The Fifth Semester Students Of English Education Department Of Teacher Training And Education Faculty Of Muria Kudus University In The Academic Year 2013/2014. 2015.

Risya Putri Dia Ocvika. TeachingLearning Pronunciation Through
Reading Aloud Technique At The Second Semester Of The Eighth Grade Of SMP Negeri 2 Gading Rejo 2016/ 2017 Academic Year, Tarbiyah And Teacher Training Faculty Raden Intan State Islamic University Of Lampung 4; p.9-15. 2017.

Amiyatul Fikriyah. An Analysis Of The Students 'Ability In By : Amaliyatul Fikriyah Of Teacher Training And Education Faculty State Institute For Islamic Studies (IAIN) Salatiga. 2019.

Yolla Kharisma Desrizon and Don Narius, Journal of English Language Teaching Improving Pronunciation In Teaching Speaking Of Senior High School Students Through English Films, Journal of English Language Teaching 6, no. 1;p.117123. 2017.

Stange, Kimberly. 2007. Using Reader's Theater and Choral Reading to Improve First Grade Regular Education Students' Fluency. Florida: University of Florida

Supiningsih. Upaya Meningkatkan Kemampuan Membaca Dalam Pelajaran Bahasa Inggris Dengan Strategi Choral Reading Melalui Powerpoint, Wacana Akademika: Majalah Ilmiah Kependidikan 1, no. 2; p.165-174. 2017.

A N Undergraduate Thesis. The Influence Of Choral Reading Method Toward Students' Reading Comprehension Ability At The Seventh Grade Of Smpn 3 Batanghari. 2017. 
Datokarama English Education Journal Vol. 2 No. 1,2021

Dhea Fernanda. "The Use Of Animation Video To Improve Students' Reading Comprehension In Narrative Text To The Second Grade Students Of Smpn 1 Lahat, South Sumatera," English Education Study Program Department Of Language And Art Education Faculty Of Teacher Training And Education University Of Lampung 2, no. 2, p.36-44, 2019.

Daniel Muijs. Ed. Doing Quantitative in education with SPPS. London: sage Publication, 2004.

Alison Mackey and Susan M. Gass. Second Language Research: Methodology and design, New York, Lawrence Erlabaum Associates, 2005.

John W. Creswell. Educational Research: Planing, Conducting, and Evaluating Quantitative and Qualitative Research, Third Edition, New Jersey: Person Education. 2008.

Naily Iffatul Maula. The use of fairy tale to students ' ability in reading narrative text (an experimental study of the eighth grade students of smp $n$ 2 banyubiru in the academic year of 2015 / 2016 )."

Ary D. Jacobs, L. C. \&Razavieh A. Introduction to research in education. Wadsworth Learning, 2002.

Cohen L. Research Method in Education (fifth ed.). London: Taylor \& Francis e- Library. p.312. 2006.
Hatch, E \& Farhady.H. "Research Design and Statistic for Applied Linguistics. p.22, 1982) 